\title{
THE EPIDEMIOLOGY OF Q FEVER
}

\author{
By E. H. DERRICK, Department of Health, Brisbane, Queensland
}

(With 1 Figure in the Text)

In 1935 the occurrence of cases of fever among meat workers in Brisbane caused concern. Investigations were begun by the Queensland Department of Health and continued in cooperation with the Walter and Eliza Hall Institute, Melbourne. The fever was found to be a rickettsiosis and to occur also among farm workers and others (Derrick, 1937; Burnet \& Freeman, 1937). It was named $\mathrm{Q}$ fever and the causative organism Rickettsia burneti. Laboratory tests (guinea-pig inoculation and serum agglutination) were devised for its accurate diagnosis (Burnet \& Freeman, 1938; Derrick, Smith, Brown \& Freeman, 1939). Between September 1935 and Augus̀t 1942, 176 cases were recognized. Much information about the mode of transmission has been obtained, and it seems desirable that this should now be reviewed, especially as the war has suspended further investigations.

All patients but two were males. Their ages ranged from 10 to 64 years. Three died.

The incidence of cases was much the same at all seasons.

\section{GEOGRAPHICAL DISTRIBUTION}

All the patients, with one possible exception, were domiciled in a coastal strip of south-east Queensland extending from Gladstone $\left(24^{\circ} \mathrm{S} ., 151^{\circ} \mathrm{E}\right.$.) to the border of New South Wales. The possible exception was a meat inspector who had worked both at Brisbane and at Cairns $\left(17^{\circ}\right.$ S., $146^{\circ}$ E.), North Queensland, before becoming ill. The most inland patients lived at Monto $\left(25^{\circ} \mathrm{S} ., 151^{\circ}\right.$ E.) and near Bell $\left(27^{\circ}\right.$ S., $151^{\circ} 30$ E.). The latter place is just over 100 miles from the sea.

The annual rainfall in the area concerned varies from 30 in. in the more inland parts to over 60 in. at the coast. Originally the wetter parts were covered by rain forest, the drier by savannah. Most is now closely settled and occupied by sugar cane, dairy, fruit or mixed farms. The area includes the city of Brisbane (population 335,000 ) and many urban centres.

Of the patients, 129 lived in Brisbane and forty-seven in the countryside.

\section{OCCUPATIONAL INCIDENCE}

The Brisbane patients were employed as shown in Table 1. All, except four laboratory workers and two men who lived on the outskirts of Brisbane, were associated with meat works.

Early in the investigations it was hoped that a study of the distribution of cases at Meat Works $\mathbf{A}$ would indicate precisely the route of infection. Disappointingly, there was no illuminating selection of occupational groups (Table 2). Workers anywhere in the establishment were liable to infection. The list included those

Table 1. Occupations of $Q$ fever patients in Brisbane

Enployees of Meat Works A (handling 83 cattle, sheep and pigs and their products)

Meat inspectors at Meat Works A

Meat canners at Meat Works A

Workers visiting Meat Works A

Workers constructing new buildings at Meat

Works A

Employees of Meat Works B (handling cattle and pigs and their products)

Laboratory workers

Worker on new sewerage construction

Relief worker

Total

Table 2. Distribution of $Q$ fever patients at Meat Works A

\begin{tabular}{lrcc} 
& \multicolumn{3}{c}{ No. of } \\
& $\begin{array}{c}\text { Average cases of } \\
\text { no. em- }\end{array}$ & $\begin{array}{c}\text { Per- } \\
\text { Deverer } \\
\text { ployed }\end{array}$ & $\begin{array}{c}\text { 1935-42 } \\
\text { centage }\end{array}$ \\
incidence \\
Foremen and clerks & 62 & 4 & $6 \cdot 5$ \\
Beef slaughter and offal & 264 & 25 & $9 \cdot 5$ \\
Calf slaughter & 47 & 3 & - \\
Sheep slaughter and offal & 100 & 8 & 8 \\
Pig slaughter and offal & 26 & 4 & - \\
Freezing & 176 & 10 & $5 \cdot 7$ \\
Tank and bone house & 57 & 13 & $22 \cdot 8$ \\
Boning room & 32 & 5 & - \\
Yard gang & 35 & 2 & - \\
Mechanical & 90 & 9 & 10 \\
Engine room & 24 & 0 & - \\
Watchmen & 22 & 0 & - \\
Various & 7 & 0 & - \\
$\quad$ Totals & 942 & 83 & $8 \cdot 8$ \\
Meat inspectors & 28 & 20 &
\end{tabular}

handling cattle, sheep and pigs. It included men skinning cattle-in contact with ectoparasites-as well as men handling meat in the canning and freezing departments. It included also a man in the fertilizer department handling only cooked, sterile material, a 
laundryman, an electrician, carpenters and visiting truck drivers.

The highest relative incidence was among meat inspectors and employees in the tank and bone house. Meat inspectors are transferred freely to and from other meat works. Each year many at Meat Works A are new arrivals. It is likely that new arrivals have an increased risk of infection, for, no doubt, many meat workers of long standing have been immunized by obvious or inapparent infections. The reason for the high incidence among workers in the tank and bone house is not evident.

The occurrence of cases at Meat Works A has seemed curiously haphazard and spasmodic. Sometimes a series of successive cases has come from the one department. Thus patients $118,119,120$ and 121 all worked in the freezing rooms. Of the twenty infections among meat inspectors in the seven years, four occurred in one period of 10 days. Sometimes a number of widely scattered burneti was obtained from three bandicoots (Isoodon torosus) (Derrick \& Smith, 1940) and six batches of bandicoot ticks (Haemaphysalis humerosa) (Smith \& Derrick, 1940). The serum of many bandicoots showed agglutination (Freeman, Smith \& Brown, 1940). (The bandicoots of the Australian region are a family-the Peramelidae - of marsupials. They and certain rodents are among the commonest animals of the Queensland bush.)

The results from Moreton Island, where the fauna is much more limited in variety than on the mainland, were interesting. There, Isoodon torosus is common. It is heavily infested with Haemaphysalis humerosa, which is, except for several species of mites, its only ectoparasite. The high infection rate among the bandicoots there (34\% showed agglutination) and among their ticks, together with the transmission experiments mentioned below, indicate that Isoodon torosus is a reservoir of infection and that Haemaphysalis humerosa is a vector among bandicoots.

Table 3. Results of tests for natural $Q$ fever

Guinea-pig inoculation

\begin{tabular}{|c|c|c|c|c|c|}
\hline \multirow{2}{*}{ Animal or parasite } & \multicolumn{3}{|c|}{ 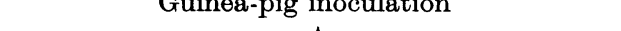 } & \multicolumn{2}{|c|}{ Serum agglutination } \\
\hline & No. tested & $\begin{array}{l}\text { No. of guinea- } \\
\text { pigs inoculated }\end{array}$ & No. positive & No. examined & No. positive \\
\hline Isoodon torosus: & & & & & \\
\hline Moreton Island & 43 & 43 & 2 & 107 & 36 \\
\hline Mainland & 60 & 60 & 1 & 73 & 3 \\
\hline Rattus c. youngi & 9 & 9 & 0 & 14 & 1 \\
\hline Hydromys chrysogaster & 6 & 6 & 0 & 13 & 2 \\
\hline Other bush animals & 27 & 27 & 0 & 34 & 0 \\
\hline Cattle & - & - & - & 984 & 14 \\
\hline \multirow{2}{*}{\multicolumn{6}{|c|}{$\begin{array}{l}\text { Ticks: } \\
\quad \text { Haemaphysalis humerosa: }\end{array}$}} \\
\hline & & & & & \\
\hline Moreton Island & 439 & 39 & 6 & - & - \\
\hline Mainland. & 63 & 13 & 0 & - & - \\
\hline Haemaphysalis bispinosa & 64 & 9 & 0 & - & - \\
\hline Boophilus a. microplus & 1160 & 16 & 0 & - & - \\
\hline Ixodes holocyclus & 220 & 29 & 0 & - & - \\
\hline Rhipicephalus sanguineus & 94 & 9 & 0 & - & - \\
\hline Mites, fleas, lice & Many & - & 0 & - & - \\
\hline
\end{tabular}

men have been infected at the same time. Thus after an interval of 4 months without a case, four men-a boner, a pig slaughterman, and two tank house workersbecame ill within 3 days. There was only one other case in the next 2 months.

Of the forty-seven country patients, thirty-two lived or worked on dairy farms. These included two femalesthe wife of one dairy farmer and the daughter of another-as well as two boys aged fourteen and ten years. Five more worked on various kinds of farms, two were timber getters, two foresters and two meat workers. The others were a bush worker, an agricultural student, a labourer in a butter factory and a man camping in the bush.

There has been no evidence of direct spread from case to case. No secondary infections have been recognized among family contacts, physicians or nurses.

\section{THE SOURCE OF INFECTION}

Naturally occurring $Q$ fever was sought in bush animals, dairy cattle and their parasites (Table 3). Rickettsia
All species of bush animals tested (seven rodents and three marsupials) were found susceptible to experimental inoculation with $Q$ fever (Derrick et al. 1940). This, together with the positive agglutinators found in the small series of Rattus culmorum youngi and water rats (Hydromys chrysogaster), suggests that other animals in the bush assist the bandicoot to provide the reservoir of infection.

The discovery of the bandicoot-tick-bandicoot cycle did not solve the problem of human infection, for Haemaphysalis humerosa does not naturally attack man, though it will feed on him, reluctantly, in the laboratory. Further, most of the patients denied having been bitten by ticks.

The next steps were the study of all the common local ticks, and the demonstration of the intermediary which carried infection from the bush reservoir to man.

\section{INVESTIGATION OF TICKS}

It was found in the laboratory that Haemaphysalis humerosa could readily become infected with Rickettsia 
burneti by feeding on infected guinea-pigs (Smith, 1940). Infection could be acquired at every instar, and was transmitted from larva to nymph and from nymph to adult. Hereditary transmission was not proved and, from the distribution of rickettsiae in the tick, seems unlikely. Infected nymphs and adults infected some of the guinea-pigs upon which they fed.

In the infected tick the rickettsiae were confined to the lining epithelium and the lumen of the gut. They were often present there in enormous numbers. The faeces were highly infective. Faecal contamination of the bite wound would be the likely mode of infection of the host.

Three other ticks, Rhipicephalus sanguineus, Ixodes holocyclus, and Haemaphysalis bispinosa could also be infected by feeding on infected guinea-pigs and could transmit infection to their host when they fed at the next stage (Smith, 1941 b, 1942a, 1942b). Each therefore is a potential vector. Each is present in the $\mathbf{Q}$-endemic area.

As all stages of Ixodes holocyclus are commonly found on mainland bandicoots, it is a likely vector of $Q$ fever among them. It bites cattle and man and may also transmit the disease to them. Several $\mathbf{Q}$ fever patients

\section{CATTLE AND THEIR TICKS}

The outstanding feature of the occupations of $Q$ fever patients has been the association with cattle. The selection of dairy farmers in the country and meat workers in the city makes it clear that infection is carried to the city by stock from the rural endemic area. (Meat workers handle also sheep and pigs. There are practically no sheep in the endemic area. Pigs are present there and have not been thoroughly investigated, but seem unlikely carriers because of their freedom from suitable parasites.)

It was found that calves could be infected experimentally with $Q$ fever (Derrick et al. 1942). They had a brief, mild illness. A serum agglutination survey showed that dairy cattle in the endemic area were being naturally infected (Table 3). These infections were inapparent.

If infected cattle were slaughtered, their blood or tissues might infect a meat worker especially if his skin was cut or abraded. But the low infectivity of cattle tissues and the infection of workers (e.g. carpenters) not actually handling meat focus attention rather on

\section{Table 4. Ticks of possible significance in the transmission of $Q$ fever}

Tick

H. humerosa

H. bispinosa

B. a. microplus

I. holocyclus

R. sanguineus

o. gurneyi
Distribution in Queensland

Eastern coastal strip $\begin{array}{cc}\text { No. of } & \text { Principal } \\ \text { hosts } & \text { host }\end{array}$

3 Bandicoot

$\begin{array}{lll}\text { South-east corner } & \mathbf{3} & \text { Cattle } \\ \text { Eastern coastal strip } & \mathbf{1} & \text { Cattle } \\ \text { Eastern coastal strip } & \mathbf{3} & \text { Bandicoot }\end{array}$

Whole state 3

Dog

Western part
Other reported hosts

Rattus rattus, R. c. youngi, opossum, cattle, horse $E$. orientalis

Sheep, horse, man, dog

Sheep

Man, most bush and

domestic animals

Sheep, cattle, horse, cat, Potential vector man

Man
Relation to $Q$ fever

Proved vector among bandicoots

Potential vector

Can be infected

Probable vector

Can be infected. Unlikely to be a vector from the country gave a history of tick bite. The ticks were not identified but the circumstances indicated Ixodes holocyclus.

Thus patient 88 , who had previously lived in the city for 6 years, began work on a forest reserve clearing, undergrowth. He developed $\mathrm{Q}$ fever 19 days later. $\mathrm{He}$ stated that during this time he had three tick bites. Patient 152, another forestry worker, said that ticks abounded after the rains began-a month before his illness.

Rhipicephalus sanguineus, the cosmopolitan dog tick, was first reported from Queensland in 1897 and is now widespread throughout the state. It has not been reported from bush animals and does not seem at present a likely vector. As, however, its principal host is susceptible to $Q$ fever (Derrick, Johnson, Smith \& Brown, 1938) and it occasionally attacks cattle and man, it is potentially important.

Ornithodorus gurneyi, a kangaroo tick, can be infected in the laboratory (Smith, 1942b). It is not present in the $\mathrm{Q}$-endemic area.

Important facts about the ticks which have been tested are set out in Table 4. There are still other ticks which may come into the story, and study also of the Trombidiid mites as possible vectors is called for. the ticks carried by the cattle. There are two species of these-Boophilus annulatus microplus (very abundant) and Haemaphysalis bispinosa.

Some Boophilus annulatus microplus, fed on one of the experimental calves, became infected. As this is a onehost tick its opportunities for spreading infection from one cow to another are limited. Crushed ticks or tick faeces would be a possible source of infection for other cattle as well as for cattlemen and meat workers.

Haemaphysalis bispinosa has a wide distribution in southern Asia. It was first recognized in Australia (in northern New South Wales) in 1911. In the last few years it has become a serious pest of cattle in several areas in south-east Queensland-areas where $Q$ fever is endemic. Though less common than Boophilus annulatus microplus, it has, as a three-host tick, greater possibilities of vectorship among cattle. Further, it has a greater host-range, which has not (in Queensland) been fully studied and may perhaps include bush animals.

\section{DISCUSSION}

The cases of $Q$ fever at Meat Works A resemble in their scattered distribution an outbreak at the National Institute of Health at Washington (Hornibrook \& Nelson, 1940). These authors suggested inhalation of 
infected dust as a possible explanation of their cases. A similar mode would go far to explain the infections among Brisbane meat workers, and might also explain some of the laboratory infections in Melbourne (Burnet \& Freeman, 1939) and in Brisbane (Smith et al. 1939). At the meat works a source of infected dust might well be tick faeces. These form a fine powder which could might carry disease from one continent to another. Many birds migrate between eastern Asia and Australia. No systematic study of their ectoparasites has been made by us, but there is one record of Haemaphysalis humerosa being found on a migratory bird (Eurystomus orientalis - the dollar bird) at Maryborough, Queensland (Smith, 1941a).

Basic cycle
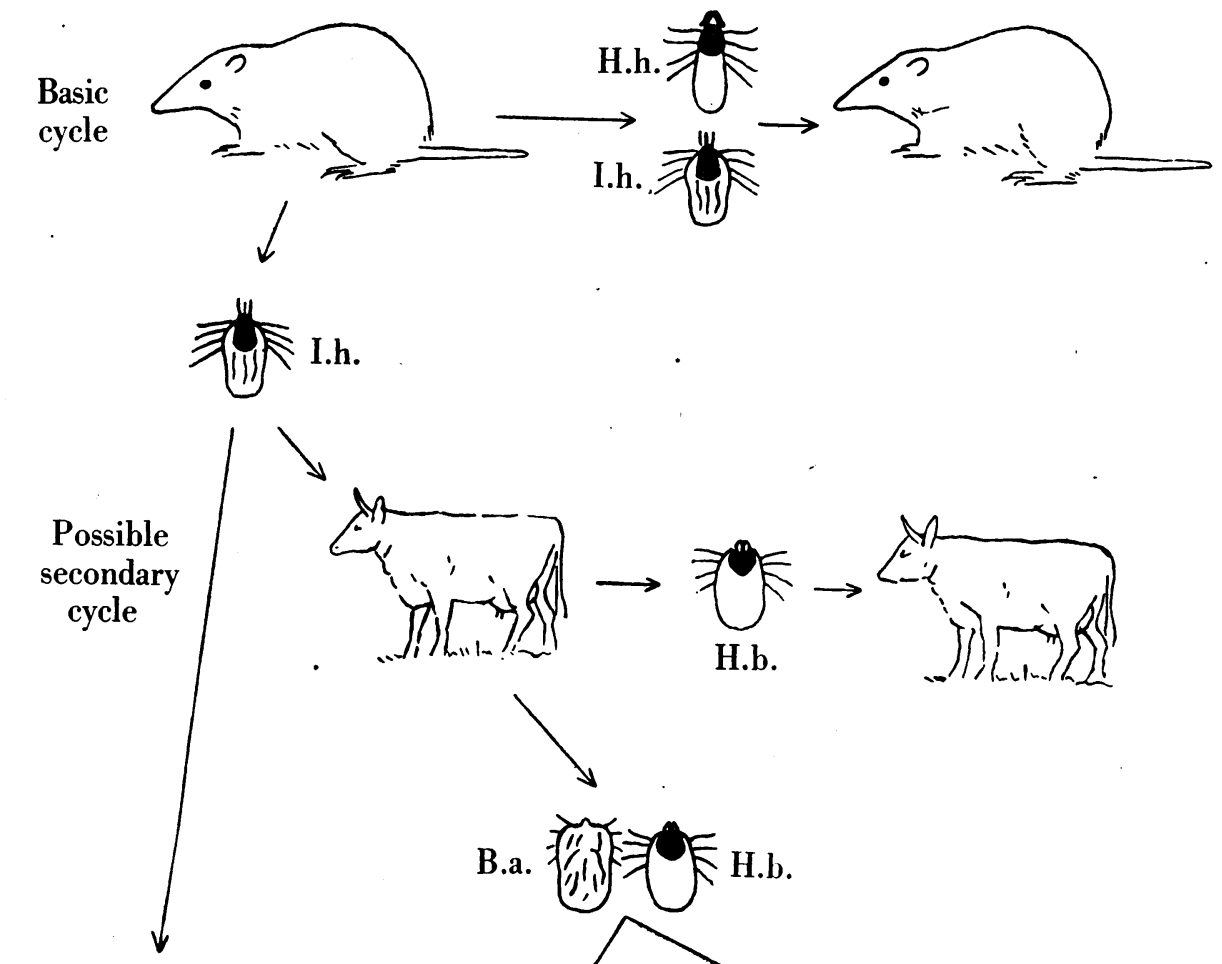

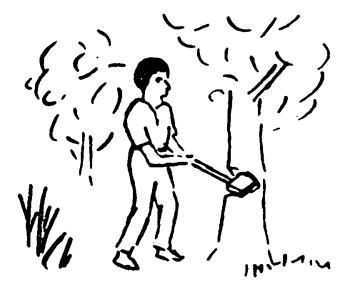

Bush worker

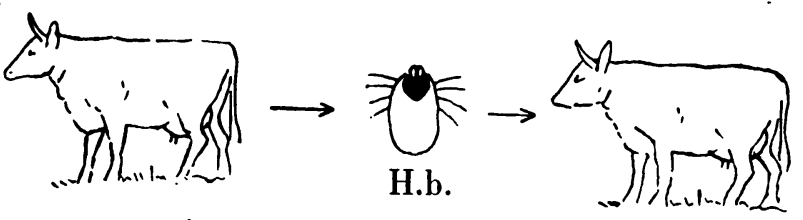

B.a.
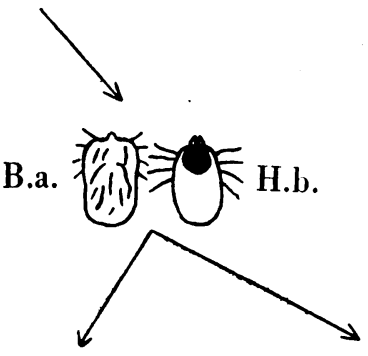

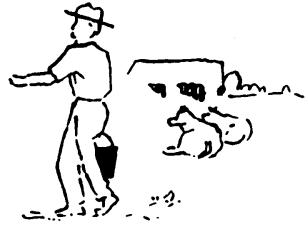

Dairy farmer

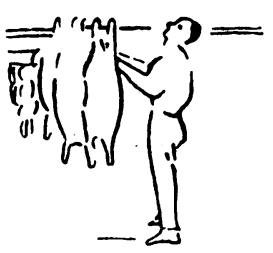

Meat worker

Fig. 1. The natural history of $\mathrm{Q}$ fever. B.a. Boophilus annulatus microplus; H.b. Haemaphysalis bispinosa; H.h. Haemaphysalis humerosa; I.h. Ixodes holocyclus.

readily be blown about in the wind. Infected tick faeces may retain their infectivity over long periods (65 and 87 days in two experiments).

The free association of Rickettsia burneti with bandicoots and their ticks on Moreton Island, where there are no cattle and very little settlement, indicates that $Q$ fever is indigenous in the Queensland bush, antedating the arrival of the white man. What genealogical relationship it bears to the $Q$ fever of America is a field for speculation. Migratory birds, if hosts of infected ticks,

\section{SUMMARY}

In seven years 176 cases of $Q$ fever have been diagnosed in Queensland. Nearly all the 129 patients who lived in Brisbane were associated with meat works. Most of the forty-seven country patients worked on dairy farms.

Investigation of native animals, cattle and ticks, has indicated in outline the natural history of 
Q fever, which is set out diagrammatically in Fig. 1. (Several steps in this outline need confirmation. and much detail remains to be filled in.)

First there is a basic cycle of infection with the bandicoot (and probably other bush animals) as reservoir, and Haemaphysalis humerosa (and probably Ixodes holocyclus) as vector. A bush worker may interrupt this cycle and get $Q$ fever from the attack of Ixodes holocyclus.

Cattle become infected, probably through Ixodes holocyclus and perhaps through other ticks. It is possible that there is a secondary cycle: cattleHaemaphysalis bispinosa-cattle.
Ticks on the cattle (Boophilus annulatus microplus or Haemaphysalis bispinosa) are probably the source of human infection. It is suggested that inhalation of tick faeces is the likely mode of entry of Rickettsia burneti.

I am grateful to Sir Raphael Cilento, Director-General of Health and Medical Services, Queensland, for his continual encouragement and for permission to publish, to Dr F. M. Burnet and Miss M. Freeman for their cooperation, to Mr G. Tomlins and his staff for much valuable information, and particularly to Messrs D. J. W. Smith and H. E. Brown who have shared the labour and the zest of the investigations.

\section{REFERENCES}

Burnet, F. M. \& Freeman, M. (1937). Experimental studies on the virus of $\mathrm{Q}$ fever. Med. J. Aust. 2, 299.

Burnet, F. M. \& Freeman, M. (1938). The rickettsia of $\mathrm{Q}$ fever: further experimental studies. Med. $J$. Aust. 1, 296.

Burnet, F. M. \& Freeman, M. (1939). Note on a series of laboratory infections with the rickettsia of $\mathrm{Q}$ fever. Med. J. Aust. 1, 11.

Derrick, E. H. (1937). Q Fever, a new fever entity: clinical features, diagnosis and laboratory investigation. Med. J. Aust. 2, 281.

Derrick, E. H., Johnson, D. W., Smith, D. J. W. \& Brown, H. E. (1938). The susceptibility of the dog to $\mathrm{Q}$ fever. Aust. J. Exp. Biol. 16, 245.

Derrick, E. H., Smith, D. J. W., Brown, H. E. \& Freeman, M. (1939). The role of the bandicoot in the epidemiology of $Q$ fever: a preliminary study. Med. J. Aust. 1, 150.

Derrick, E. H. et al. (1940). The susceptibility of various animals to $\mathrm{Q}$ fever. Aust. J. Exp. Biol. $18,409$.

Derrick, E. H., Smith, D. J. W. \& Brown, H. E. (1942). The role of the cow in the transmission of human Q fever. Aust. J. Exp. Biol. 20, 105.

Derrick, E. H. \& SMITH, D. J. W. (1940). The isolation of three strains of Rickettsia burneti from the bandicoot Isoodon torosus. Aust. J. Exp. Biol. 18, 99.
Freeman, M., Smith, D. J. W. \& Brown, H. E. (1940). Surveys of .human and animal sera for Rickettsia burneti agglutinins. Aust. J. Exp. Biol. 18, 193.

Hornibrook J. W. \& Nelson, K. R. (1940). An institutional outbreak of pneumonitis. I. Epidemiological and clinical studies. Publ. Hlth Rep. 55, 1936.

Smith, D. J. W. (1940). The transmission of $Q$ fever by the tick Haemaphysalis humerosa. Aust. J. Exp. Biol. 18, 103.

Sмiтн, D. J. W. (1941 a). The biology of Haemaphysalis humerosa Warburton \& Nuttall (Acarina, Ixodidae) in Queensland. Aust. J. Exp. Biol. 19, 73.

Smrth, D. J. W. (1941b). The transmission of $Q$ fever by the tick Rhipicephalus sanguineus. Aust. J. Exp. Biol. 19, 133.

Smith, D. J. W. (1942a). The transmission of $Q$ fever by the tick Ixodes holocyclus (with notes on tick paralysis in bandicoots). Aust. J. Exp. Biol. 20, 213.

Sмгтн, D. J. W. (1942b). Experimental infection of the ticks Haemaphysalis bispinosa and Ornithodorus sp. with Rickettsia burneti. Aust. J. Exp. Biol. 20, 295.

Smith, D. J. W., Brown, H. E. \& DerRICK, E. H. (1939). A further series of laboratory infections with the rickettsia of $\mathrm{Q}$ fever. Med. J. Aust. 1, 13.

Smith, D. J. W. \& Derrick, E. H. (1940). The isolation of six strains of Rickettsia burneti from the tick Haemaphysalis humerosa. Aust. J. Exp. Biol. 18, 1.

(MS. received for publication 24. v. 43.-Ed.) 